\title{
Excessive Exercise, Self-Respect and Olympic Education: Legacy in Rio de Janeiro-2016
}

\author{
Thiago Guimarães* \\ Laboratory of Exercise Physiology (LAFIEX), Estácio de Sá University (UNESA), Rio de Janeiro, Brazil
}

Submission: May 14, 2018; Published: May 21, 2018

*Corresponding author: Thiago Guimarães, Laboratory of Exercise Physiology (LAFIEX), Estácio de Sá University (UNESA), Rio de Janeiro, Brazil,

Email: thiagotguimaraes@yahoo.com.br

\section{Opinion}

Although hundreds of years ago it is believed that sports and gymnastics are essential to the development of the human body to optimize functional capacity and mind [1], increasingly research in the sciences of exercise and sport shows the beneficial effects of exercise, in addition to the International Olympic Committee try to propagate the idea "sports to protect the health" [2] and "well-being and healthy lifestyle" [3], we are experiencing a worldwide pandemic of physical inactivity [4]. Physical inactivity is one of the main causes related to the development of non-communicable chronic diseases, such as cardiovascular diseases, diabetes, several types of cancer, mental disorders, bones and joints [5]. According to the World Health Organization 2012, in addition to causing suffering, functional dependence, intangible costs on health systems and reduced quality of life, these diseases account for $58.5 \%$ of all deaths worldwide.

On the other hand, physicians speculate that excess of exercise impacts negatively in health since years before Christ [6]. Side effects of physical training can represent the same public health problem in comparison of physical inactivity [7], but we can observe that the culture of pain without moderation is a reality among competition or recreation athletes, coaches and others sports. We can see that athletes not only in our times but also in ancient times suffered from overtraining and health injuries due to extreme exercise [8].

Olympic Games and its values were the most influential sporting phenomenon in western civilization, impacting in the development of health and democracy [9]. The cult of physical effort and harmony, that is, the excess combined with moderation is one of the numerous ideas inherent to Olympic education [10]. One of the main objectives of Olympic Education and Olympic Movement is to provoke reflection about essential values related to human development, gradually committed in the modern world by capital power. In addition to tolerance, equality, fair play, truce, excellence and joy of effort [3], Olympic
Education has also the role of discussing the promotion of health, respect for oneself, your body and that of the other.

The promotion of health, although already considered by researchers and professionals of Physical Education and Sports Sciences in different countries, has not received enough attention in the context of Olympic Education. The subject health promotion appeared during the ancient Olympic Games since the care of athletes and prevention of injuries was specialist services provided by instructors. Discussions in this context are important because of their educational dimension and the understanding that health promotion is directly related to Olympic principles and values.

Unpublished data from our laboratory (LAFIEX-UNESA) indicate that physical education students from a Brazilian city are not able to identify the broad meaning of Olympism besides the crucial idea of harmony and moderation in training. Statistics revealed that less than half of our sample with 433 students answered correct options about Olympism and paradox of exercise and training. Although Rio de Janeiro has hosted the last Olympic Games, the legacy in this area of Olympic Education is questionable. Olympic Education in university could provoke future physical education teachers to rethink paradigms, as the culture of pain without moderation, and values associated to the human progress, as an appreciation of sports and health with balance and responsibility [11].

Physical inactivity is a public health problem and overtraining can also contribute to the development of pathologies and reduction of quality of life. Olympic Education seems to be a tool to stimulate discussions that promote people's health through exercise and sports. Integration policies between International and National Olympic Committees could provide training for university professors in relation to Olympic Education. University students and future professionals, in turn, could multiply and spread their diverse contents in society. 


\section{References}

1. Kleisiaris CF, Fakianakis C, Papathanasiou IV (2014) Health care practices in ancient Greece: The Hippocratic ideal. J Med Ethics Hist Med 7: 6 .

2. (2007) International Olympic Committee: Olympic Charter. Laussane, Switzerland.

3. (2013) International Olympic Committee: Olympic Charter. Laussane, Switzerland.

4. Hallal PC (2012) Global physical activity levels: Surveillance progress, pitfalls, and prospects. Lancet 380(9838): 247-257.

5. Handschin C, Spiegelman BM (2008) The role of exercise and PGC1alpha in inflammation and chronic disease. Nature 454(7203): 463-469.

This work is licensed under Creative

Commons Attribution 4.0 License

DOI: 10.19080/JPFMTS.2018.04.555627
6. Albanidis E (2013) Exercise in Moderation: Health Perspective of Hellenic Antiquity. Nikephoros 26: 33-62.

7. Guimarães TT, Terra R, Dutra P (2017) Chronic effects of exhausting exercise and overtraining on the immune response: Th1 and Th2 profile. Journal Motricidade 13(3): 69-78.

8. Matta Mello Portugal E (2013) Neuroscience of exercise: From neurobiology mechanisms to mental health. Neuropsychobiology 68(1): 1-14.

9. Crowther NB (2007) Sport in Ancient Times. Praeger, London, UK.

10. Reppold Filho AR (2009) Olimpismo e Educação Olímpica no Brasil. UFRGS, Porto Alegre, Brazil.

11. Lee IM (2012) Effect of physical inactivity on major non-communicable diseases worldwide: An analysis of burden of disease and life expectancy. Lancet 380(9838): 219-229.

\section{Your next submission with Juniper Publishers will reach you the below assets}

- Quality Editorial service

- Swift Peer Review

- Reprints availability

- E-prints Service

- Manuscript Podcast for convenient understanding

- Global attainment for your research

- Manuscript accessibility in different formats ( Pdf, E-pub, Full Text, Audio)

- Unceasing customer service

Track the below URL for one-step submission https://juniperpublishers.com/online-submission.php 